\title{
VE STOPÁCH ROBERTA SMETANY ANEB TŘETÍ ŠKOLA ČESKÉ HUDEBNÍ VĚDY
}

\section{Úvodem}

Když přišel dvaatřicetiletý doktor Robert Smetana v roce 1936 z Brna za Bedřichem Václavkem do Olomouce, připadal si trochu jako ve snu. Ve srovnání $\mathrm{s}$ Brnem se ocitl v provinčním a konzervativním maloměstě, avšak získal zde dobré zaměstnání a ležela před ním spousta úkolů i jedinečných výzev. Postupně se uplatnil jako osvětový a muzejní pracovník, hudební folklorista, hudební kritik, spoluobnovitel olomoucké univerzity, vysokoškolský pedagog, muzikolog, organizátor i pečovatel o odkaz svého spolupracovníka Bedřicha Václavka (který zahynul v roce 1943 v Osvětimi).

Během prvního tuctu let svého olomouckého působení vydal publikace hudebně folkloristické (jako spolueditor s Bedřichem Václavkem): České písně kramářské, Český národni zpěvník a Sušilovy Moravské národni pisně; hudebně regionalistické: O nový český hudební život; obecně historiografické: dodnes cenného Průvodce památkami v Olomouci; ale i spisy na mezinárodně nosná témata jako Vyprávěni o Leoši Janáčkovi a později O misto a význam skladatelského díla Dvoŕákova v českém hudebním vývoji (1956).

Při tomto výčtu nás zarazí tematická širre, ba dokonce trríšt' zaměření oněch vědeckých prací a odborných činností. To vyvolává otázku: Kým vlastně byl Robert Smetana? Tradovaná odpověd’, že „nebyl typem kabinetního vědce“, nestačí. Je nutno doplnit, že Smetana nebyl pouze vědcem, ale nuceně i všestrannou osobností a doslova budovatelem, který $\mathrm{v}$ malých olomouckých poměrech a skromných podmínkách (tj. málo lidí na velké množství úkolů) musel zastat a vykonat mnohé. Tím zároveň vložil do vínku olomoucké muzikologii některá specifika: zájem o sféru lidové, resp. funkcionální, resp. nonartificiální hudby, zaměření na regionální, ale pokud možno i nadregionální témata, př́prava středoškolských učitelů hudební výchovy v duchu koncepce Helfertovy, organizační pragmatismus, a také budování a prosazování „třetího“ pracoviště mezi Prahou a hudebně vědeckým Brnem, dnes pokud možno i v mezinárodním kontextu. Tyto stopy Roberta Smetany, vedoucí někdy až do současnosti, se pokusím sledovat. 


\section{Stopy institucionální a personální}

Robert Smetana (1904-1988) ${ }^{1}$ byl jednou z klíčových osobností podílejících se v roce 1946 na obnově olomoucké univerzity. ${ }^{2}$ (K tomu mi v sedmdesátých letech $\mathrm{s}$ lehce ironickým úsměvem sdělil: „,v Olomouci nebylo po válce do čeho píchnout, tak jsme museli obnovit univerzitu“.) Od 20. záŕí 1946 byl pověřen přednáškami a cvičeními z hudební vědy a výchovy i vedením př́íslušného mezifakultního Ústavu pro hudební vědu a výchovu. Na olomoucké univerzitě se stal od 1. května 1951 prvním docentem a od 1. ř́ijna 1965 prvním profesorem hudební vědy. Své pracoviště, přejmenované v roce 1950 na katedru, vedl šestadvacet let - až do roku 1972. Jeho zániku a sloučení s katedrou hudební výchovy na Pedagogické fakultě Univerzity Palackého v roce 1980 velmi želel. Kontakty s bývalými mladšími kolegy udržoval i po svém přestěhování do Brna, které nastalo $\mathrm{v}$ roce 1982.

Ovlivnil řadu předních osobností české muzikologie a hudebního života. Byli to např́klad (abecedně) Alena Burešová, Josef Bek, Karel Boženek, Ratibor Budiš, Jaroslav Bužga, Milena Černohorská, Ladislav Daniel (starší i mladší), Oldřich Duzbaba, Zdeněk Fridrich, Vladimír Gregor, Vladimír Hudec, Leo Jehne, Jan Kapusta, Olga Kittnarová, Pavel Klapil, Ctirad Kohoutek, Josef Kotek,

1 Prof. PhDr. Robert Smetana, DrSc. (narozen 29. srpna 1904 ve Vídni, zemřel 6. října 1988 v Brně), muzikolog a hudební folklorista. Před př́ichodem do Olomouce (1936) zapisoval lidové písně na Dačicku, odkud pocházel jeho rod. Pracoval v hudebním archivu Moravského zemského muzea v Brně, absolvoval studijní pobyt v brněnském Státním ústavu pro lidovou píseň (dnešním Etnologickém ústavu Akademie věd ČR). V Olomouci pak spolupracoval s literárním teoretikem Bedřichem Václavkem (narozen 10. ledna 1897 v Čáslavicích, zahynul 5. března 1943 v Osvětimi). Společně připravili souhrnnou edici sběratelského díla Františka Sušila Moravské národni písně s nápěvy do textu vřaděnými (1941, tři reprinty, poslední 1998), vydali také Český národní zpěvník a edice České písně kramářské a České světské písně zlidovělé I, Písně epické, Svazek první: Slovesný, hudebni a obrazový materiál písní. Ze Smetanova podnětu vznikla v roce 1958 tradice uměnovědných konferencí Václavkova Olomouc, která přispěla k výraznému posílení Olomouce jako centra hudebně folkloristického bádání. Jako muzikolog vydal Smetana monografie O nový český hudební život: 10 let Volného sdruženi prátel moderni hudby v Olomouci 1927-1937 a 10 let Spolku pro komorni hudbu v Olomouci 1937-1947 (1947), O misto a význam skladatelského dila Dvoŕákova v českém hudebním vývoji (1956) a byl i vědeckým redaktorem Československé vlastivědy IX, Umění, sv. 3 - Hudba (1971) a dvousvazkových Dějin české hudebni kultury 1890-1918 $(1972,1981)$. Ze Smetanových studií ke klíčovým pracím patří Hudební vývoj a jeho členěni - Teze k periodizaci dějin hudby (1972), v níž prezentoval svou koncepci vývoje dějin hudby jako organického propojení lidové a umělé kultury, Mozarts Musik im Lied tschechischer Bänkelsänger (1956), Mozart und das tschechische Volk (1958), K otázce vztahů mezi řeči a hudbou (1976), Smetanova Vltava a jeji melodická tematika (1979), ale i práce věnované vlastivědě či kulturním památkám regionu, jako např. Dvě olomoucké okupační památkár̆ské vzpomínky (1987) či Průvodce památkami v Olomouci (se Z. Princem a L. Machytkou, 1966). Viz také VIČAROVÁ, Eva. In ceskyhudebnislovnik.cz, 10. března 2010, a sborník BUREŠOVÁ, Alena (ed.). Hudba v Olomouci. Historie a současnost II. In honorem Robert Smetana. Olomouc: Univerzita Palackého, 2004.

2 Byl tajemníkem akčního výboru pro obnovu olomoucké univerzity a patřil k nejbližším spolupracovníkům prvního rektora Josefa Ludvíka Fischera. 


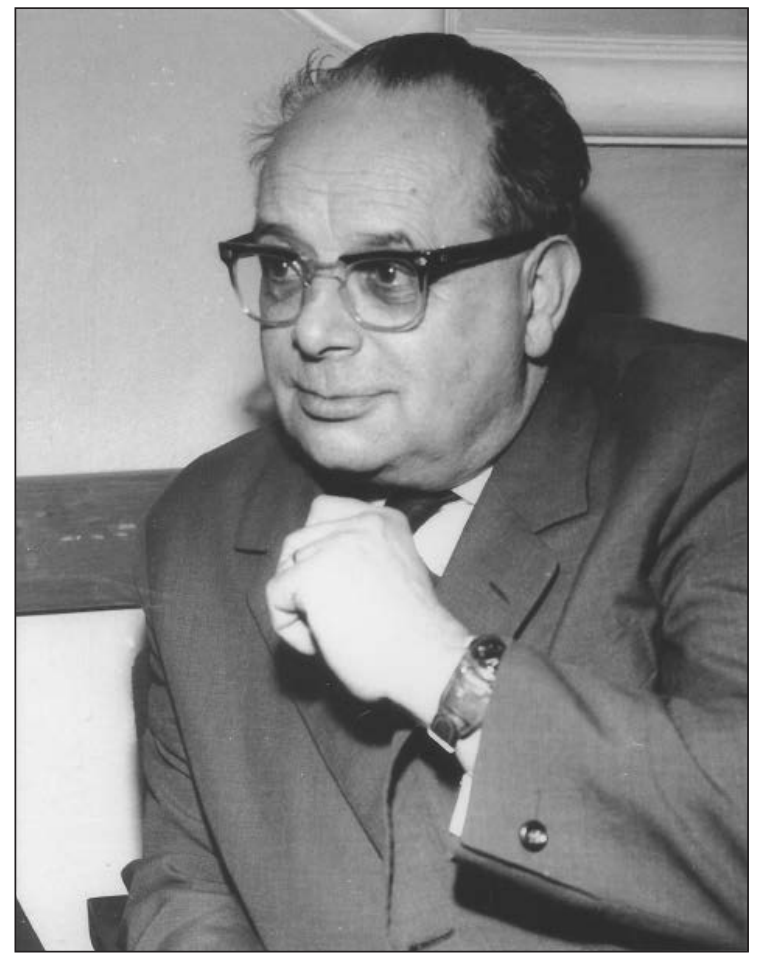

Obr. 1. Robert Smetana (1904-1988), foto archiv Univerzity Palackého v Olomouci

Dagmar Kučerová, Arne Linka, Jitka Ludvová, Jiří Macek, Miroslav Malura, Jan Mazurek, Miloš Navrátil, František Ostrý, Theodor Pártl, Jiří Pilka, Oldřich Pukl, Václav Ptáček, Jiří Sehnal, Marie Skalická, Karel Steinmetz, Alois Suchanek, Robert Šálek, Evžen Valový, Jan Vičar, Tomislav Volek, Gustav Vožda, Luděk Zenkl, a to jako své př́mé žáky, nebo jako adepty na titul doktor filozofie (PhDr.) či kandidát věd o umění (CSc.). Na UP habilitoval Miroslava Karla Černého a Vladimíra Hudce. ${ }^{3} \mathrm{~V}$ pedagogické a vědecké oblasti zpočátku se Smetanou spolupracovali zejména hudební historik a regionalista Vladimír Gregor, hudební historik a kritik Vladimír Hudec, ostravský skladatel a teoretik Josef Schreiber, dómský regenschori Gustav Pivoňka a hudební pedagog František Kratochvil, v pozdějších letech hudební pedagog a akustik Luděk Zenkl, skladatel Pavel Čotek, hudební psycholog a pedagog Libor Melkus a další. Díky Smetanovu působení vznikla v Olomouci třetí česká muzikologická škola.

3 Miroslav K. Černý se habilitoval v roce 1968 spisem K problematice metodologie hudebně historické práce a byl jmenován docentem v roce 1969. Vladimír Hudec byl habilitován v roce 1972 na základě spisu Zdeněk Fibich - monografie. Tematický katalog díla Zdeňka Fibicha. 


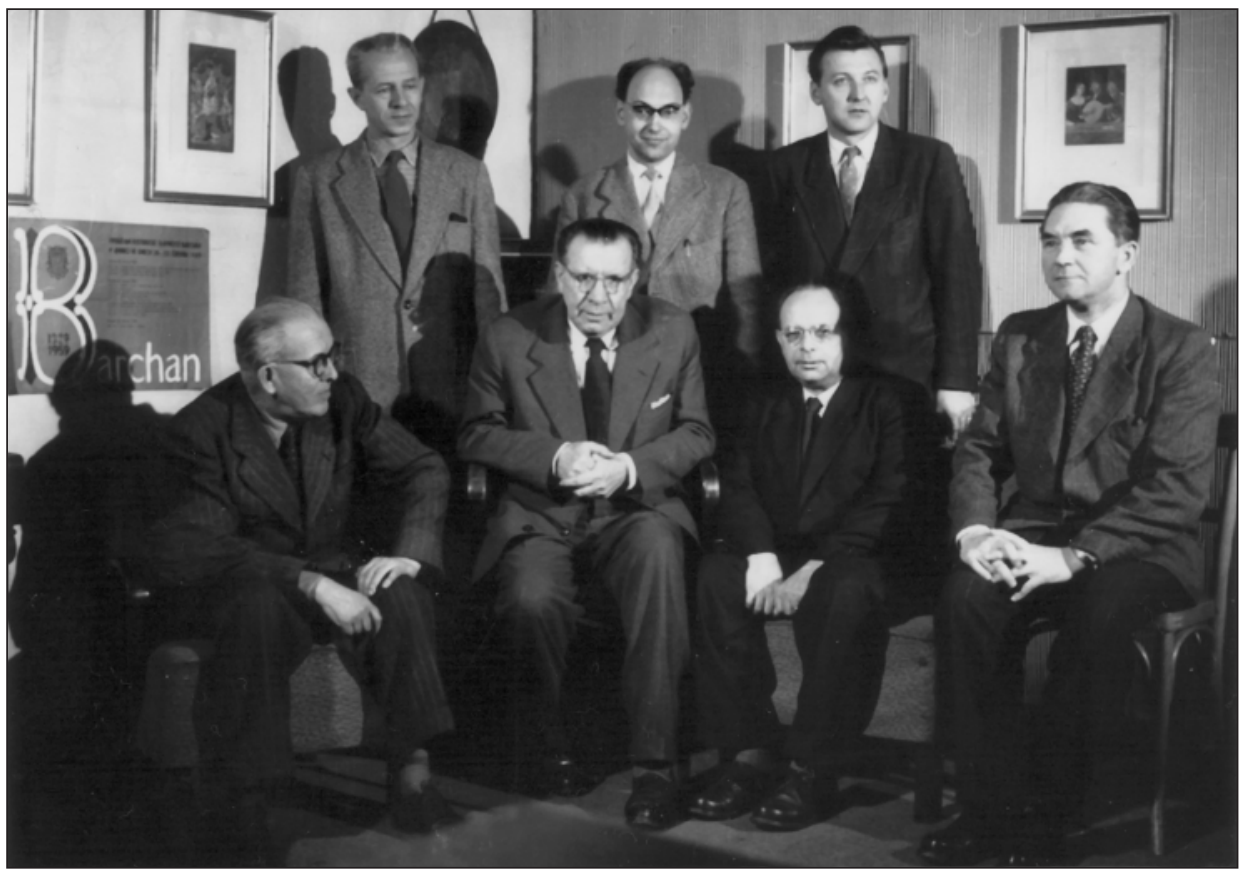

Obr. 2. Pedagogové katedry hudební vědy a výchovy Filozofické fakulty Univerzity Palackého v Olomouci, zleva stojící Pavel Čotek, Václav Rábl, Vladimír Hudec, sedící Gustav Pivoňka, Josef Schreiber, Robert Smetana a František Kratochvil, kolem roku 1960, foto archiv Univerzity Palackého v Olomouci

Další klíčovou osobností olomoucké hudební vědy a představitelem její „druhé muzikologické generace“ byl Smetanův žák Vladimír Hudec (1929-2003). ${ }^{4}$ Jako Smetanův asistent začal působit již od roku 1951 ve svých dvaadvaceti letech. Vedení katedry od Smetany převzal v roce 1972 a pracoviště vedl až do jeho

4 Prof. PhDr. Vladimír Hudec, CSc. (narozen 10. prosince 1929 v Olomouci, zemřel 12. září 2003 v Brně), po studiu na Slovanském gymnáziu studoval v letech 1947-1951 hudební vědu, francouzštinu a estetiku na UP, kde byl mimo jiné žákem Roberta Smetany a Bohumila Markalouse. Od roku 1951 působil jako asistent na Ústavu hudební vědy a výchovy, resp. katedře hudební vědy a výchovy, v letech 1973-1980 toto pracoviště vedl. V letech 19731987 vykonával na Filozofické fakultě a následně na Pedagogické fakultě funkci proděkana. Poté přesídlil do Brna, kde v letech 1987-1990 zastával funkci rektora Janáčkovy akademie múzických umění a pedagogicky zde působil až do roku 2000. Od roku 1990 až do roku 2003 byl jedním z klíčových pedagogů obnovené olomoucké katedry muzikologie a na sklonku života se znovu přestěhoval do Olomouce. Habilitoval se v roce 1972 na Filozofické fakultě UP a profesorem byl jmenován 1984. Působil v celé řadě odborných celostátních orgánů a komisí a redakčních rad. Byl významným znalcem díla Zdeňka Fibicha, vydal monografie Fibichovo skladatelské mládí. Doba přprav (1966), Zdeněk Fibich (1971) a zvláště Tematický katalog tvorby Zdeňka Fibicha (2001). Zabýval se také dějinami hudby olomoucké opery a po celý život pozorně sledoval olomouckou hudební kulturu jako náročný i citlivý hudební kritik. Podrobněji o něm viz VIČAR, Jan. In ceskyhudebnislovnik.cz, 13. ledna 2010. 
zrušení v roce 1980, kdy spolu s ostatními kolegy přešel na Pedagogickou fakultu Univerzity Palackého. Univerzitním profesorem dějin hudby na Univerzitě Palackého se stal v roce 1984.

Hudcovým stěžejním badatelským zaměřením bylo dílo Zdeňka Fibicha a hudba 19. století. Stal se také předním olomouckým hudebním kritikem a popularizátorem i akademickým funkcionářem. V letech 1987 až 1990 působil jako rektor Janáčkovy akademie múzických umění. V roce 1990 začal jako profesor dějin české a světové hudby vyučovat znovu na Univerzitě Palackého a v polovině devadesátých let se do Olomouce z Brna zase navrátil a přestěhoval.

Existence katedry hudební vědy a výchovy na Filozofické fakultě UP byla ukončena $\mathrm{v}$ důsledku reorganizace vysokého školství a rozhodnutím Ministerstva školství v roce 1980. Její dosavadní pracovníci byli převedeni na „integrovanou“ katedru hudební vědy a výchovy Pedagogické fakulty UP. ${ }^{5}$

Se změnou poměrů po listopadu 1989 byly na Filozofické fakultě UP vytvořeny podmínky pro obnovení „Smetanovy katedry“, což bylo požadováno již na

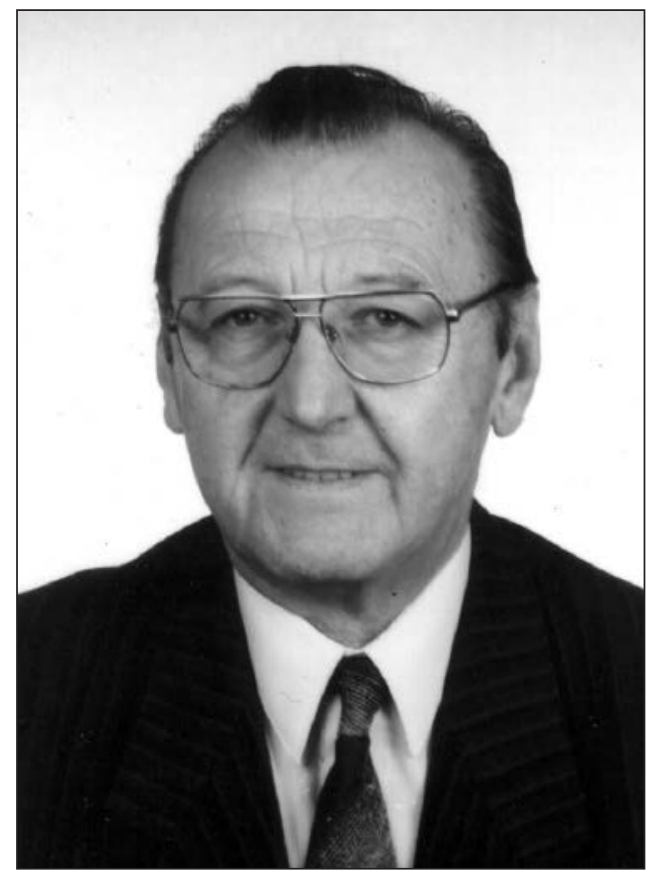

Obr. 3. Vladimír Hudec (1929-2003), foto archiv

5 Po mém soudu nemohl Hudec proti zrušení „Smetanovy katedry“ nic učinit. Přesto si vzpomínám, jak na něj v roce 1980 skladatel Pavel Čotek v afektu křičel: „To by se za Roberta Smetany nestalo! Smetana by to nedopustil!“ 


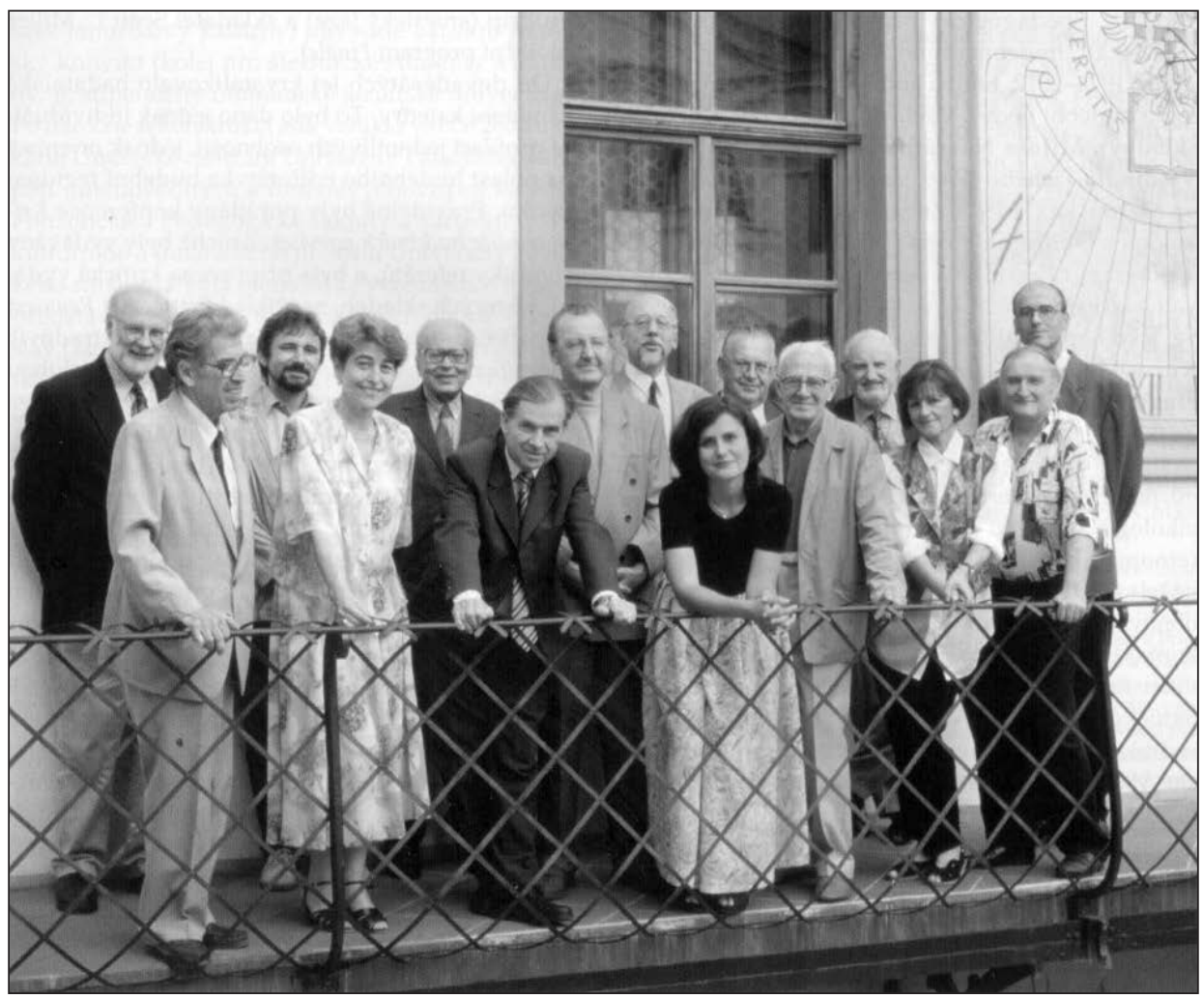

Obr. 4. Pedagogové katedry muzikologie Filozofické fakulty Univerzity Palackého v Olomouci na ochoze budovy Kř́žkovského 8: zleva Kenton Frohrip (St. Cloud State University, Minnesota), Miroslav Karel Černý, František Havelka, Alena Burešová, Jaroslav Jiránek, Jiří Sehnal, Vladimír Hudec, Jan Vičar, Lenka Křupková, Stanislav Běhal, Pavel Čotek, Ivan Poledňák, Zdeňka Slámová (sekretářka), Stanislav Tesař a Vladimír Tichý, 5. září 1997, foto Adolf Jankovský

setkání bývalých absolventů této katedry v červnu $1989 .{ }^{6}$ Zásadní krok byl učiněn hned počátkem roku 1990 z iniciativy teatrologa Jiř́ího Stýskala (1928-2014), kdy byla vytvořena katedra věd o umění se samostatnou muzikologickou sekcí. Od záŕí 1990 pod hlavičkou katedry věd o umění a od září roku 1992 již v rámci samostatné katedry muzikologie došlo k rychlému formování olomoucké muzikologie, a to poprvé v její čisté odborné podobě. Na rozdíl od prvotní Smetanovy koncepce byl totiž zformován ,hudebně vědecký seminář podle starého, před-

6 Setkání absolventů oboru hudební věda a hudební výchova studujících na Filozofické fakultě Univerzity Palackého v letech 1946-1981 se konalo v Olomouci dne 10. června 1989. Viz o tom podrobněji ve stati hodnotící provedené reformy v oblasti vysokého školství i tehdejší stav př́ípravy učitelů hudební výchovy na středních školách - VIČAR, Jan. Nad setkáním absolventů jedné katedry. Hudební rozhledy, 1989, roč. 37, č. 11, s. 525-526. 


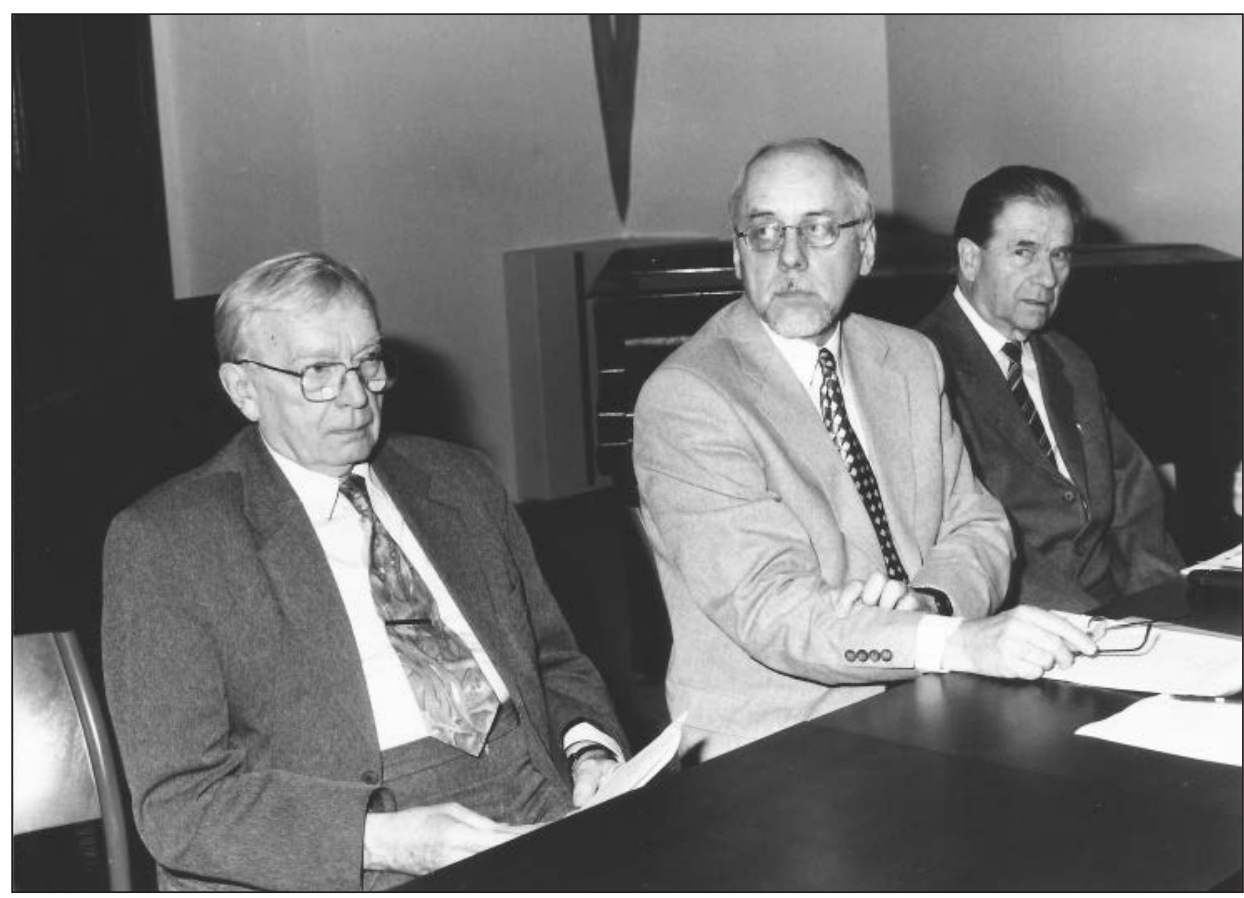

Obr. 5. Účastníci konference Hudba v Olomouci-Historie a současnost II, Luděk Zenkl, Jan Vičar a Jiří Sehnal, 24. listopadu 2003, foto Adolf Jankovský

válečného střihu“",7 obdobný vysokoškolským ústavům v Praze a Brně. Př́pravu středoškolských profesorů hudební výchovy i nadále v Olomouci zajištovala katedra hudební výchovy Pedagogické fakulty UP.

Hlavním hybatelem tohoto dění byl Jan Vičar (1949), ${ }^{8}$ poslední žák Roberta Smetany a žák Vladimíra Hudce, který vedl nové pracoviště se dvěma přestávkami až do konce roku 2011, tedy celkem osmnáct let. Formoval katedru spíše v souladu s anglo-americkou muzikologickou tradicí, pro niž byl charakteristický velký podíl hudebně teoretických a praktických disciplín. Vičar dával výukový prostor také hudebnímu editorství, teorii populární a jazzové hudby, etnomuzikologii a hudebnímu managementu.

Nedostatek dalších specialistů Vičar řešil - podobně jako kdysi Smetana - povoláním pedagogů na částečný úvazek či externistů odjinud - mnohdy starších,

Toto zaměření v roce 1946 Robert Smetana odmítl - srovnej níže poznámku č. 10.

Prof. PhDr. Jan Vičar, CSc. (1949), absolvent ostravské konzervatoře (akordeon), hudební výchovy a češtiny na Filozofické fakultě UP (1972) a oboru skladba na Akademii múzických umění v Praze (1981). V roce 1985 získal titul kandidáta věd o umění na základě práce Stylové tendence v díle Václava Trojana, habilitoval se roku 1988 na Hudební fakultě Akademie múzických umění v Praze, druhou habilitaci získal v roce 1995 na UP na základě práce Václav Trojan. Na UP byl také v roce 1998 jmenován profesorem pro obor teorie a dějiny hudby. 


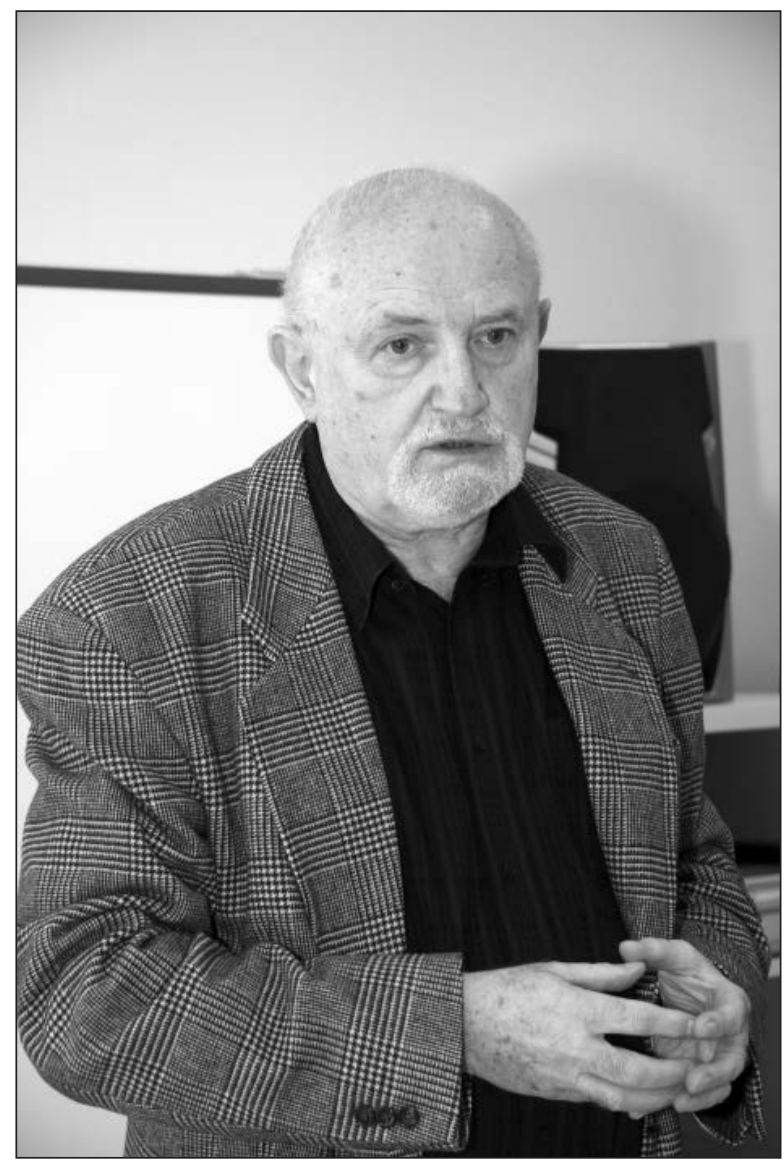

Obr. 6. Ivan Poledňák při prezentaci své knihy Hudba jako problém estetiky na Univerzitě Palackého v Posluchárně Roberta Smetany dne 21. listopadu 2006, foto Adolf Jankovský

v některých př́padech z různých důvodů „,volných“, či ochotných pomoci. To přivedlo do Olomouce řadu vynikajících hudebních osobností v čele s Ivanem Poledňákem (1931-2009), ${ }^{9}$ který se stal v roce 1994 v pořadí třetím (po Smeta-

9 Prof. PhDr. Ivan Poledňák, DrSc. (narozen 31. prosince 1931 ve Velkém Meziříčí, zemřel 5. ř́jina 2009 v Praze), muzikolog, pedagog, publicista a organizátor, absolvent oboru hudební věda a estetika na Masarykově univerzitě v Brně. V roce 1968 dosáhnul hodnosti doktora filozofie na Karlově univerzitě v Praze, o rok později zde získal titul kandidáta věd o umění. Jako jeden z mála muzikologů obdržel hodnost doktora věd o umění (DrSc.), habilitoval se v roce 1992 na Masarykově univerzitě v Brně. Na olomoucké katedře muzikologie působil od roku 1992 nejprve externě. Historicky třetím profesorem teorie a dějin hudby Univerzity Palackého v Olomouci byl jmenován v roce 1994. Patřil k předním specialistům na problematiku hudební psychologie, hudební estetiky a sémiotiky, průkopnickou pozici zastával v oblasti výzkumu dějin jazzové a populární hudby. Jeho muzikologické dílo je mimořádně rozsáhlé, je autorem či spoluautorem čtrnácti monografií, stovek odborných článků a studií, autorem řady kritik, recenzí apod. O jeho přínosu olomoucké muzikologii viz studie VIČAR, 
novi a Hudcovi) olomouckým profesorem hudební vědy. Vyučoval v Olomouci od roku 1992 hudební sémiotiku, hudební estetiku, hudební psychologii, teorii a dějiny nonartificiální hudby. Určující osobností byl zejména v letech 19982000 a 2003-2007, kdy podvakrát vystř́́dal Jana Vičara ve vedení katedry.

Olomoucká muzikologická škola byla rozvíjena nejen zásluhou vůdčích osobností, ale i podněty přicházejícími od dojížděících pedagogů, například Mikuláše Beka (1964, hudební sociologie) a Stanislava Tesaře (1940, stará hudba, hudební paleografie, hudební management). Zásadní poznatky přinesly vědecké monografie o Pavlu Vejvanovském, Adamu Michnovi a barokních varhanách na Moravě od Jiř́ího Sehnala (1931, dějiny hudby 17. a 18. století), velký byl také vědecký či pedagogický př́nos Jaroslava Jiránka (1922-2001, hudební sémiotika), Miroslava K. Černého (1924-2012, hudba antických kultur, metodologie hudební vědy), Václava Kučery (1928, teorie skladby), Miloše Navrátila (1932, dějiny hudby), Vladimíra Tichého (1946, teorie skladby), Vlastislava Matouška (1948, etnomuzikologie) a Zuzany Jurkové (1961, etnomuzikologie). Specifikem se stala několikaletá působení zahraničních pedagogů, jimiž byli Američan Paul Christiansen (1967, etnomuzikologie, hudba 20. století) a Brit, resp. Australan Gregory Hurworth (1949, etnomuzikologie, Gustav Mahler aj.), kteří přednášeli studentům $v$ angličtině. Mezi vědecké spolupracovníky katedry lze přiřadit i Jiř́ího Vysloužila (1924), který se stal na limitované období členem výzkumného týmu projektu „Morava a svět" a v roce 2014 vydal v Olomouci pozoruhodnou publikaci Dvě stě let české hudby na Moravě.

Zatímco olomouckými studenty byli v sedmdesátých letech mimo jiné Eva Ocisková, Stanislav Pecháček a Jana Vašatová, po obnově muzikologických studií v devadesátých letech se počet výrazných absolventů a doktorandů rozhojnil. Byli jimi např́klad (abecedně) Jana Adámková, Radim Bačuvčík, Jan Blüml, Lucie Brázdová, Lenka Dohnalová, Božena Felgrová, Tomáš Hanzlík, František Havelka, Jiř́ Höhn, Helena Chaloupková, Zuzana Jurková, Jindra Keferová, Marek Keprt, Jiří Kopecký, Jan Košulič, Markéta Koptová, Tomáš Kráčmar, Václav Kramář, Matěj Kratochvíl, Markéta Kratochvílová, Lenka Křupková, Alice Kučerová, Petr Lyko, Vítězslav Mikeš, Jan Přibil, Ingrid Silná, Martina Stratilková, Věra Šímová-Morgan, Věra Šustíková, Václav Vraný, Eva Vičarová a Martin Vořriššk.

\section{Další olomoučtí badatelé}

Hudebněvědné bádání se v menší míře pěstovalo i na katedře hudební výchovy Pedagogické fakulty Univerzity Palackého, jejíž základní poslání ovšem bylo

Jan. Ivan Poledňák jako olomoucká hudební osobnost. In Acta Universitatis Palackianae Olomucensis, Musicologica Olomucensia IX. In honorem Ivan Poledñák, Facultas Philosophica, Philosophica-Aesthetica 33, Lenka Křupková (ed.). Olomouc: Univerzita Palackého, 2007, s. 37-41. Viz také př́slušné heslo, které vypracovali Mikuláš Bek, Petr Macek a Karel Steinmetz, In ceskyhudebnislovnik.cz, 6. října 2009. 


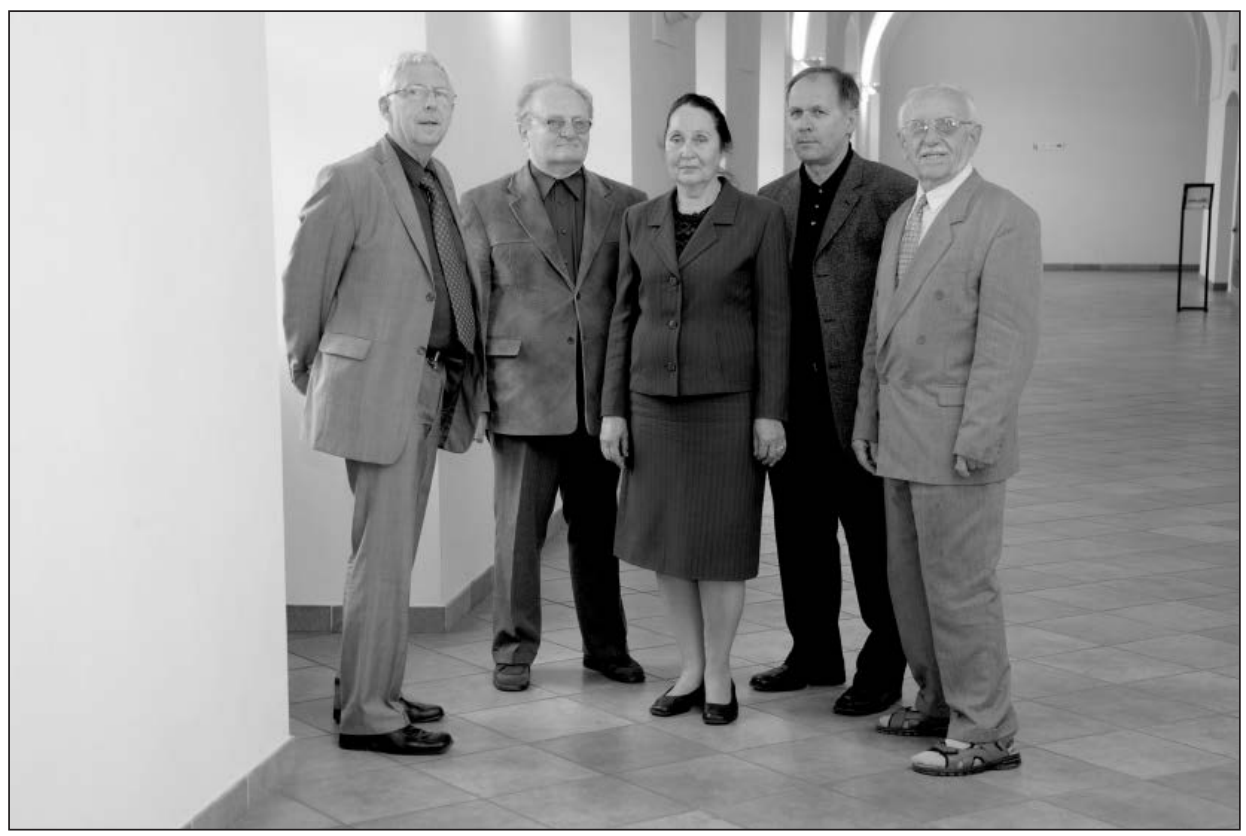

Obr. 7. Pět vedoucích katedry hudební výchovy Pedagogické fakulty Univerzity Palackého: zleva Karel Steinmetz, Pavel Klapil, Svatava Střelcová, Jiří Luska a Ladislav Daniel (starší), 2009, foto Petr Zatloukal

přirozeně jiné. Na tomto pracovišti působili již před ,integrací“ Ladislav Daniel (1922-2015), který se zaměřoval na obecnější reflexi a apologetiku svých hudebně výchovných záměrů, organolog Zdeněk Fridrich (1927-2002) a hudební folklorista Pavel Klapil (1937). Velkou badatelskou posilou se stal od roku 1989 Karel Steinmetz (1945), zaměřený na dílo Leoše Janáčka a dějiny české hudby 20. století, jenž od roku 1993 převzal i vedení katedry. Některé pozoruhodné práce vydali také mladší badatelé, mezi nimi zejména Jiř́i Luska (1951) reflektující otázky hudební pedagogiky a hudební psychologie, Lubomír Spurný (1965), specialista na dílo Henricha Schenkera a Aloise Háby, dnes ovšem spjatý s brněnskou muzikologií, muzikolog a skladatel Vít Zouhar (1966) zaměřený na historii hudební postmoderny a korespondenci Bohuslava Martinů, a jiní.

Respekt vůči oblasti hudební vědy projevila Univerzita Palackého i tím, že jmenovala některé hudební vědce svými čestnými doktory. Jejím vůbec prvním doktorem honoris causa byl v roce 1949 Zdeněk Nejedlý: ten ovšem spíše z politických a společenských důvodů jako ministr podporující vytvoření Univerzity Palackého, ale nesporně i v souladu s muzikologickým stanoviskem Roberta Smetany. Naposledy to byl v roce 2014 americký hudební vědec specializující se na českou hudbu Michael Beckerman.

V současnosti převzala štafetu vysokoškolské výuky a bádání čtvrtá olomoucká muzikologická generace, jež je tvořena až na výjimky novodobými absolventy 


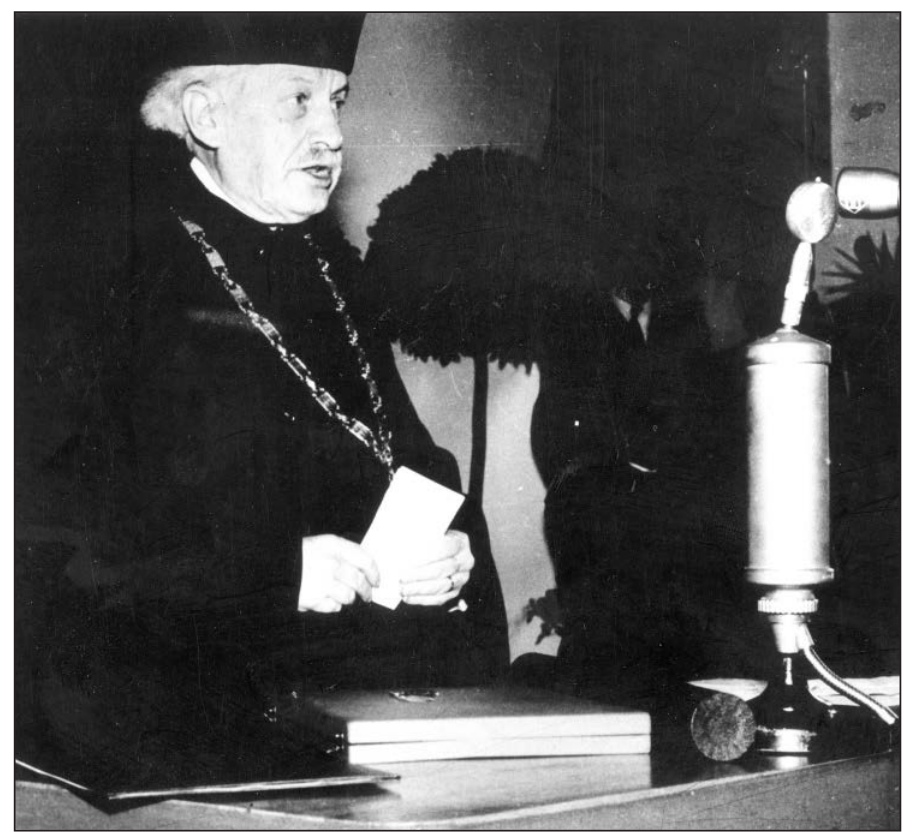

Obr. 8. Zdeněk Nejedlý při udělení čestného doktorátu filozofie, 25. června 1949, foto archiv UP

obnoveného pracoviště. Vedoucí katedry muzikologie se stala od 1. ledna roku 2012 Lenka Křupková (1970), která se dosud badatelsky zaměřila na dílo Vítězslava Nováka a německou operu v Olomouci, dalšími docenty jsou Jiř́i Kopecký (německá opera v Olomouci, Zdeněk Fibich) a Eva Vičarová (vojenská hudba, hudba v olomoucké katedrále).

\section{Stopa pedagogická - stř̌edoškolští profesoři hudební výchovy}

Profilace katedry byla Smetanou vymezena dvěma základními liniemi, a to př́pravou odborných učitelů hudební výchovy na středních školách a odborným muzikologickým výzkumem. Smetana akcentoval zaměření na výchovu středoškolských učitelů hudební výchovy jako specifikum, které odlišovalo olomouckou katedru od pracoviště pražského a brněnského. ${ }^{10}$ Tato linie byla při obnově

10 Sám Smetana k tomu ve svém rukopisu věnovanému vzniku a rozvoji katedry hudební vědy a výchovy uvedl: „V rámci tohoto, obnovováni “ univerzity v Olomouci mél $R$. S. tedy docela nevšedni možnosti koncipovat nově budované učiliště netradičně: zatímco na pưdě ostatních univerzit $v$ Československu byly obnovovány hudebněvědecké semináře podle starého, předválečného střihu, realizoval R. S. jako prvý u nás studium hudebni výchovy pro učitele středních škol. Navazoval tehdy na odkaz svého krátce předtím zemrelého univerzitního učitele Vladimira Helferta [...]. Viz SMETANA, Robert. Katedra hudebni vědy a výchovy filosofické fakulty Univerzity Palackého v Olomouci, její vznik a rozvoj [4 strany strojopisu], 


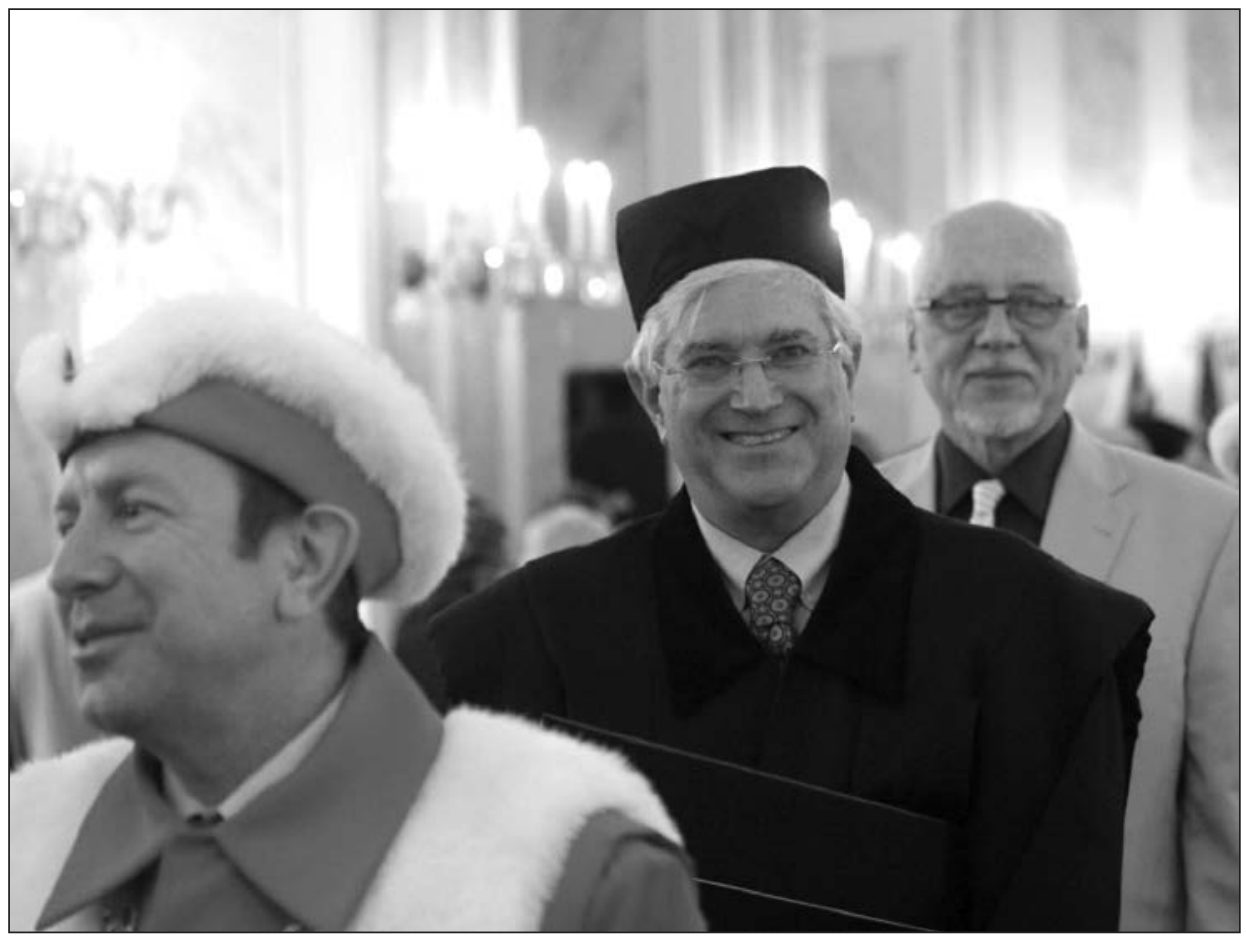

Obr. 9. Michael Beckerman (uprostřed) čestným doktorem Univerzity Palackého, 12. listopadu 2014, foto Pavel Konečný

pracoviště v roce 1990 studiem čisté muzikologie oslabena, avšak nadále se v plné míře realizuje na Pedagogické fakultě.

\section{Stopa folkloristická a nonartificální hudba}

Smetanovy práce hudebně folkloristické mají zásadní i inspirující význam dodnes. Je to nesporně také proto, že Robert Smetana byl nejen folkloristou, ale především muzikologem. V roce 1975 se vyjádřil takto: „Díky V. Helfertovi jsem se nestal folkloristou, nýbrž studoval lidový zpěv jako muzikolog, tj. byl jsem schopen vidèt lidovou písen̆ z pozic symfonie stejně jako naopak symfonii z pozic lidového zpěvu [...], a naučil jsem se chápat hudbu komplexně jako homogenní a vnitřně kontinuální jev, ve kterém každý projev, lhostejno zda lidová píseň anebo symfonie, je si navzájem rovnýv tom, že je apriorně (krom talentem) podmíněn jak užitými hudbotvornými prostředky, tak specifickým ideovým podnětem a nábojem, a to se všemi důsledky této formule pro pojetí a hlavně zkoumání hudby

1970. Pozůstalost Roberta Smetany, Archiv Národního muzea, inv. č. 153, NAD č. 323, sign. 1183 , s. 1. 
jako jedné z řádných složek každého jednotlivého lidského života $i$ života lidských pospolitostí."“11

I když se v Olomouci nepodařilo na Smetanovu folklorní linii systematicky navázat a jedinou důležitou osobností se stal v tomto směru Smetanův žák Pavel Klapil, přece si pracoviště uchovalo velkou vnímavost a otevřenost vůči ,jiné hudbě“. Tak se v Olomouci již od poloviny sedmdesátých let učila „Teorie a dějiny funkcionální hudby" (vyučoval ji Jan Vičar) a tato orientace pak byla prosazena jako jedna ze stěžejních linií Ivanem Poledňákem. Zároveň se v Olomouci jako na první české hudebněvědné katedře začala vyučovat v polovině devadesátých let etnomuzikologie (Zuzana Jurková, Vlastislav Matoušek).

\section{Stopa historiografická - regionalistika versus světovost}

Robertem Smetanou byly dány olomoucké muzikologii do vínku hudební historiografie a regionalismus, ale zároveň i ambice zaměřit se v souladu s rozhodnutím konkrétního badatele i na celonárodní nebo mezinárodní témata. Vedle hudební vlastivědy a zkoumání díla Dvořákova, Janáčkova, Fibichova i tvůrců českého baroka se tak někteří akademikové zabývali zejména českými skladateli 20. století (např́iklad Milanem Báchorkem, Pavlem Bořkovcem, Janem Klusákem, Išou Krejčím, Vítězslavem Novákem, Václavem Trojanem) či bádali v oblasti systematických hudebních disciplin. Nejsvětovějšími tématy současné nejmladší generace je tvorba Nikolaje Skrjabina (Marek Keprt), fenomenologie v hudební estetice (Martina Stratilková) a rocková hudba (Jan Blüml). Celkové odborné zaměření pracoviště vyplývá z níže uvedeného přehledu knižních monografií vydaných olomouckými muzikology nebo jinými muzikology v době jejich olomouckého působení.

Knižní monografie vydané v období 1945-2014 olomouckými či jinými muzikology v době jejich olomouckého působení:

- Robert Smetana, O nový český hudební život, 1947,

- Robert Smetana, Průvodce památkami v Olomouci, 1948; 1966,

- Robert Smetana, Vyprávění o Leoši Janáčkovi, 1948,

- Robert Smetana (s Bedřichem Václavkem), České světské písně zlidovělé I, Písně epické, Svazek první: Slovesný, hudebni a obrazový materiál písní, 1955,

- Vladimír Gregor, Hudební vlastivěda Olomouckého kraje, 1956,

- Robert Smetana, O misto a význam skladatelského díla Dvoř́kova v českém hudebním vývoji, 1956,

- Vladimír Gregor, Česká dětská píseň umělá, 1959,

11 Smetana, který se celkově považoval nikoli za folkloristu, ale za muzikologa, vyjádřil obdobné stanovisko i jinde, viz např́klad SMETANA, Robert. Můj muzikologický př́nos. In Hudba v Olomouci Historie a současnost II. In honorem Robert Smetana. Olomouc: Univerzita Palackého, 2004, s. 52. 
- Vladimír Gregor, Olomoucká a vídeňská léta skladatele A. Förchtgotta-Tovačovského, 1959 ,

- Vladimír Gregor, Vývoj hanáckého národopisu, zvláště zpěvu a hudby, 1959,

- Vladimír Hudec, Fibichovo skladatelské mládí. Doba př́prav, 1966,

- Vladimír Hudec, Zdeněk Fibich, 1971,

- Luděk Zenkl, Temperované a čisté ladění v evropské hudbě 19. a 20. století, 1971,

- Luděk Zenk1, ABC hudebni nauky, 1971,

- František Kohoutek, Houslová hra ve světle soudobé vědy, 1983,

- Jan Vičar, Akordeon a jeho hudebni uplatnéní, 1984,

- Olga Hrabalová - Pavel Klapil, V Zábřeze na rynku (lidové písně severní Moravy), 1987,

- Pavel Klapil, V Lipniku včil jarmak bude, 1989,

- Jan Vičar, Václav Trojan, 1989,

- Mikuláš Bek, Vybrané problémy hudebni sociologie, 1993,

- Alena Burešová, Pavel Bořkovec, 1994,

- Karel Steinmetz, Artikulace času v Janáčkově hudbě. Př́spěvek k analýze časově pohybových struktur Janáčkových děl a $k$ využití těchto analýz v hudební praxi, 1994,

- Miroslav K. Černý, Hudba antických kultur, 1995,

- Jaroslav Jiránek, Hudebni sémantika a sémiotika, 1996,

- Jurková Zuzana, Kapitoly o mimoevropské hudbě, 1996,

- Karel Steinmetz, Jan Šoupal - sbormistr, pedagog a človék, 1997,

- Jan Vičar - Roman Dykast, Hudebni estetika, 1997,

- Jiř́ Sehnal, Jan Vičar a kolektiv, Philippus Jacobus Rittler: Requiem Claudiae Imperatricis, 1998,

- Jan Vičar, Hudebni kritika a popularizace hudby, 1998,

- Miroslav K. Černý, Kapitoly z metodologie hudebni védy, 1998,

- František Havelka, Muzikolog a počítač. Úvod do studia počítačové editace hudby, 1998,

- Pavel Klapil, Záhorský zpěvník, 1999,

- Pavel Klapil, Olomoucká brána (metropole střední Moravy v lidových písních), 2000,

- Ivan Poledňák, Úvod do problematiky hudby jazzového okruhu, 2000,

- Lubomír Spurný, Heinrich Schenker - dávný neznámý, 2000,

- Vladimír Hudec, Zdeněk Fibich. Tematický katalog, 2001,

- Ivan Poledňák - Jiří Fukač, Úvod do studia hudebni védy, 2001,

- Jiří Sehnal - Jiř́i Vysloužil, Dějiny hudby na Moravě, 2001,

- Miroslav K. Černý, Nástin vývoje symfonie, 2002,

- Eva Vičarová, Rakouská vojenská hudba 19. století a Olomouc, 2002,

- Alena Burešová, Cantus iuventutis, 2003,

- Miloš Navrátil, Déjiny hudby, 2003,

- Jiří Sehnal, Barokni varhanářství na Moravě. Díl 1. Varhanáři, 2003,

- Ivan Poledňák, Vášeň rozumu. Skladatel Jan Klusák-člověk, osobnost, tvůrce, 2004, 
- Pavel Režný, Aspekty reprodukce Janáčkovy sborové tvorby pro mužské sbory, 2004,

- Jiří Sehnal, Barokni varhanářství na Moravě. Díl II. Varhany, 2004,

- Karel Steinmetz, Hukvaldská poéma Milana Báchorka, 2004,

- Vít Zouhar, Postmoderní hudba? Německá debata na sklonku 20. století, 2004,

- Jan Vičar, Imprints. Essays on Czech Music and Aesthetics, 2005,

- Lenka Křupková, Studie ze života a dila Vitézslava Nováka, 2006,

- Jiř́ Luska, Vývoj sluchu pro harmonii v ontogenezi, 2006,

- Pavel Režný, Od folklorních kořenů po soudobou hudbu, 2006,

- Vít Zouhar - Zdeněk Zouhar, Milý přteli. Dopisy Bohuslava Martinů Zdeňku Zouharovi. Dear friend. Bohuslav Martinů's Letters to Zdeněk Zouhar, 2006,

- Lenka Křupková, Vitězslav Novák - Universal Edition Wien. Korespondence 1910-1935, 2007,

- Ivan Poledňák a kolektiv, Proměny hudby v měnicím se světě, 2007,

- Ingrid Silná, Francisco Carlo Müller: Messa in A di Dominica pro tempore Nativitatis vel alio, 2007,

- Jiř́i Kopecký, Opery Zdeňka Fibicha z devadesátých let 19. století, 2008,

- Jiř́i Sehnal, Pavel Vejvanovský and the Kroměřiz Music Collection, 2008,

- Jiří Kopecký, Zdeněk Fibich. Stopy života a díla, 2009,

- Ingrid Silná, Hudba ve farním kostele sv. Václava v Tovačově, 2009,

- Jiří Sehnal, Adam Michna z Otradovic: Missa sancti Wenceslai, 2010,

- Ingrid Silná, Chrámový pěvecký sbor náboženské obce Církve československé husitské v Olomouci-Hodolanech, 2010,

- Filip Hajdu, Hudební život v Mohelnici a Lošticich po roce 1945, 2011,

- Jiř́i Kopecký - Markéta Koptová, Richard Batka a hudební život Čechůa a Němců v Praze, 2011,

- Petr Lyko, Die Orgel im Gebiet von Jeseník, Olomouc, Prostějov, Přerov und Šmperk in den Jahren 1860-1960, 2011,

- Ingrid Silná, Ezechiel Ambros, 2011,

- Lucie Brázdová, Hudba a kardinál Dietrichstein 1599-1636, 2012,

- Gabriela Coufalová, At’život náš jest harmonií.../Harmonie sei unser Leben...., 2012,

- Jiří Kopecký, Německá operni scéna v Olomouci I (1770-1878), 2012,

- Lenka Křupková, Německá operní scéna v Olomouci II (1878-1920), 2012,

- Jiří Sehnal, Adam Michna: Magnificat, 2012,

- Robert Smetana, Vzpomínky na Rudolfa Firkušného, (posthum.) 2012,

- Martina Stratilková, Vývoj fenomenologického myšlení o hudbè, 2012,

- Eva Vičarová, Hudba v olomoucké katedrále, 1872-1985, 2012,

- Jiří Sehnal, Adam Michna z Otradovic - skladatel, 2013,

- Ingrid Silná, František Perna. Učitel a hudebni skladatel, 2013,

- Jan Blüml - Jan Košulič, Olomoucké Free Jazz Trio, 2014,

- Jan Vičar a kolektiv: Hudba v Olomouci 1945-2013, 2014,

- Jiří Vysloužil, Dvě stě let české hudby na Moravě, 2014. 
Během období 1993-2013 vzniklo na olomoucké katedře muzikologie 189 bakalářských, 89 magisterských a 20 disertačních prací - a některé pozoruhodné spisy byly vytvořeny rovněž na katedře hudební výchovy. Vzrůstající počet absolventů, tiskem vydaných studií a monografí i vysoká kvalita mnohých diplomových prací vedly $\mathrm{k}$ tomu, že se vědecká výkonnost olomoucké muzikologie

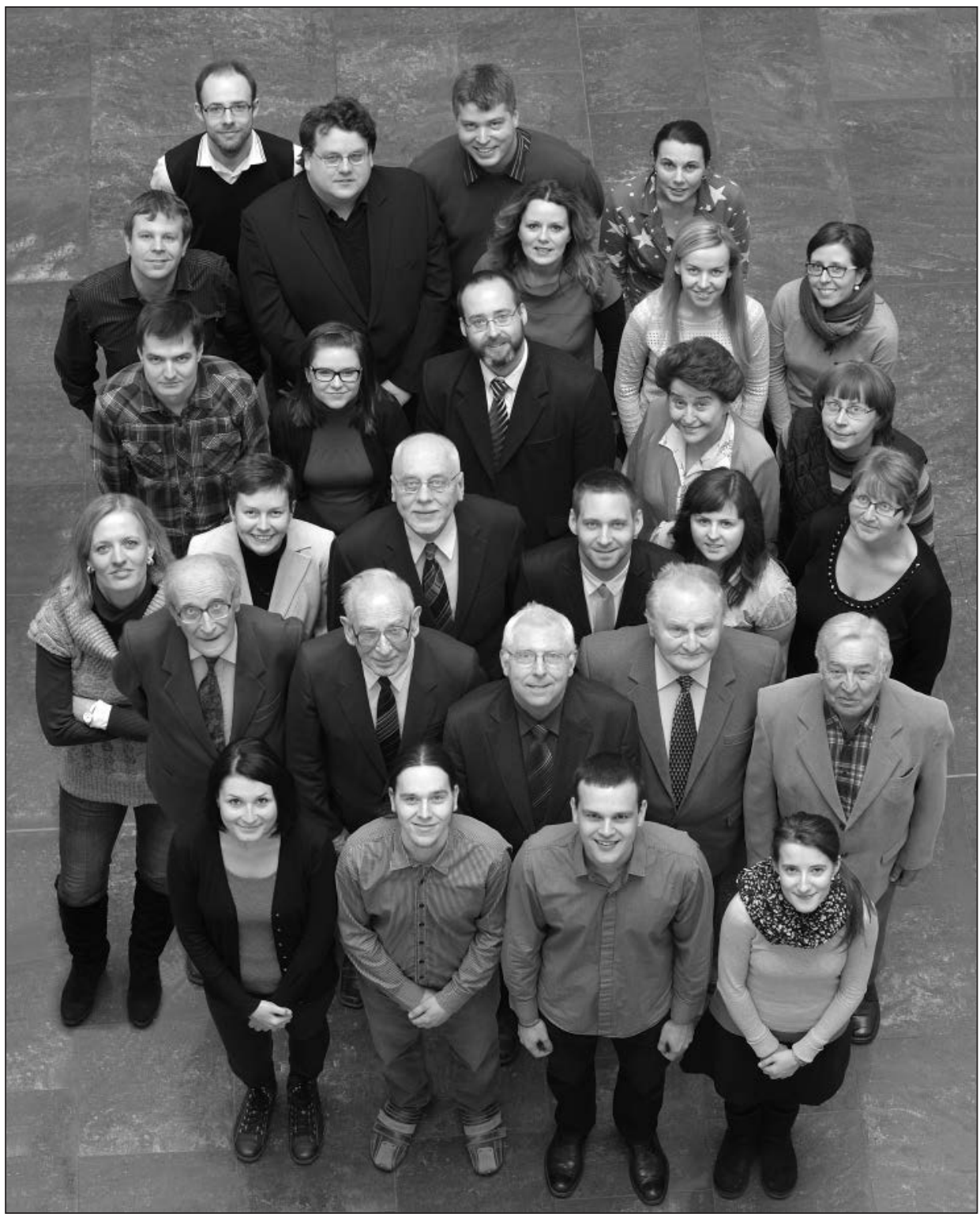

Obr. 10. Představitelé třetí české muzikologické školy? Autoři publikace Hudbav Olomouci 1945-2013 v Atriu Uměleckého centra Univerzity Palackého, 17. února 2014, foto Petr Zatloukal 
stala během posledního dvacetiletí srovnatelná s výkonností a produkcí zavedených muzikologických ústavů v Praze a Brně. Olomoučtí muzikologové a jejich diplomanti sice většinou neřešili „světová témata“, avšak přsesto přispěli k hudebněvědnému bádání kvalitními a nezanedbatelnými položkami.

Druhou stranou téže mince byla skutečnost, že pracoviště sice vychovávalo „vzdělané lidí“, kteří si „,svůj obor dobrovolně vybrali“ (jak ř́kával v devadesátých letech Vladimír Hudec), avšak kteří přirozeně jen málokdy našli trvalejší uplatnění ve svém oboru. $\mathrm{V}$ důsledku ekonomických a kvantitativních ukazatelů a tlaků v rrízení českého vysokého školství během posledních desetiletí i olomoucké pracoviště - podobně jako zejména ústav brněnský - přispělo $\mathrm{k}$ nepřiměřené a dosud nebývalé „muzikologizaci Čech i Moravy“. S těmito tendencemi jako

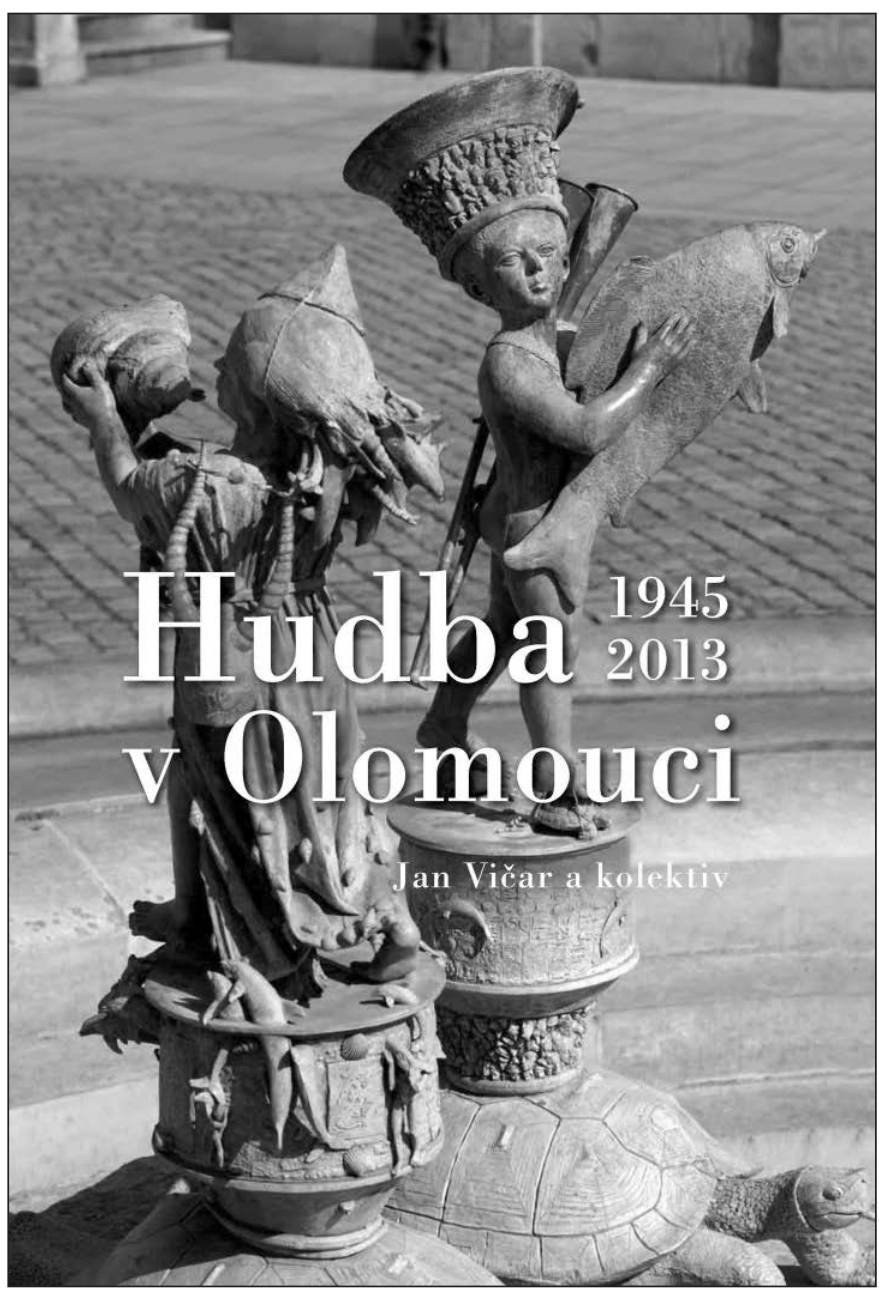

Obr. 11. Obálka dosud poslední olomoucké hudebněvědecké publikace z roku 2014 
důsledku preference kvantity (financování oborů podle počtu získaných studentů) nad kvalitou by patrně Robert Smetana bytostně nesouhlasil. ${ }^{12}$

Sledování zrodu, rozvoje, útlumu i oživení třetího centra muzikologického bádání v České republice lze uzavř́t poukazem na rozsáhlou syntetickou publikaci Hudba v Olomouci 1945-2013. Byla vytvořena kolektivem 32 autorů (včetně doktorandů a studentů) v rámci výzkumného záměru „Morava a svět: Umění v otevřeném multikulturním prostoru“ a vydána na sklonku roku 2014. Uvádí jména přibližně 4600 osobností a zachycuje na ploše zhruba 1200 normostran textu a prostřednictvím 570 fotografií, notových ukázek a obrazových materiálů komplexní dějiny hudby středomoravské metropole posledních desetiletí. I když mezinárodní dopad této knihy bude zanedbatelný, také ona rozvíjí důstojným způsobem mnohostranný a inspirativní odkaz Roberta Smetany.

Jan Vičar (janvicar@seznam.cz), Katedra muzikologie, Filozofická fakulta, Univerzita Palackého, Olomouc; Katedra teorie a dějin hudby, Hudební a taneční fakulta, Akademie múzických umění, Praha.

\section{ABSTRACT \\ IN THE TRACK OF ROBERT SMETANA OR THE THIRD SCHOOL OF CZECH MUSICOLOGY}

The credit for the foundation of a musicological institution at the restored university in Olomouc in 1946 goes to Vladimír Helfert's disciple, Robert Smetana (1904-1988). In 1951 he became associate professor and in 1965 professor and was at the head of the Department (originally an institute) of Musicology and Music Education until 1972. It was due to him that the third Czech school of musicology was established in Olomouc, thus joining the earlier academic institutions in Prague and Brno. Smetana's department concentrated on the training of professional teachers of music education at secondary schools as well as on research and thus helped to produce publications of Czech musicologists.

Research in music has been successful in producing individual monographs from the history of Czech music (monographs on composers, the work of Zdeněk Fibich, etc.), in the field of systematic musicology (organology, music theory, music aesthetics and criticism, study of folklore music), and in long-term research into the history of music in Moravia (Baroque music in Moravia, history of music in Olomouc, history of the German opera in Olomouc, music in the Olomouc Cathedral, etc.) A selective list of the monographs published as books has some eighty items.

\section{Key words}

Robert Smetana, Vladimír Hudec, Ivan Poledňák, Jan Vičar, Jiří Sehnal, Lenka Křupková, Czech musicology, Olomouc, Palacký University

\section{Bibliography}

VIČAR, Jan et al. Hudba v Olomouci 1945-2013. Olomouc: Univerzita Palackého, 2014.

12 Rovněž Jan Vičar jako vedoucí olomoucké katedry muzikologie kvantifikační tendence na rozdíl od jiných odmítal, avšak vzhledem k ekonomickým tlakům a celkové koncepci vysokého školství promítajícím se i do poměrů na Filozofické fakultě UP to bylo málo účinné. Srov. např́klad zápis z 29. schůze katedry muzikologie Filozofické fakulty UP konané dne 28. února 2007. 